\title{
Victor Cojocaru, Bibliographia classica orae septentrionalis Ponti Euxini (BCOSPE). Vol. I: Epigraphica, numismatica, onomastica \& prosopographica (= Pontica et Mediterranea 2), Cluj-Napoca: MEGA Publisher, 2014, 560 pp. + 1 CD ROM
}

[Disclosure: The readers should be aware that, as a friend of the author and as a member of the editorial board of Pontica et Mediterranea, I have seen through various stages of the development of this bibliographic project. When asked to write a review nevertheless, I accepted after some hesitation, so that I might contribute to the dissemination of this unique research tool among Classical scholars.]

B COSPE I is a remarkable achievement, a milestone not only within the study of the Ancient History of the Black Sea coast, but also for the collaboration of and constructive dialogue between scholars of Western and Eastern Europe. The book is dedicated to Heinz Heinen (19412013), who was not only one of the most eminent scholars of the Black Sea in Antiquity, but also one of the forerunners of this truly international dialogue and exchange between nations, ideologies and disciplines. A short but vivid Forschungsbericht that outlines the development of Black Sea Studies in modern times forms the introduction. It is interwoven with glimpses of V. Cojocaru's personal experience gained over the last two decades: these saw him scrutinizing libraries and archives as much as cooperating with excavation teams, in scholarly caucuses, on conferences and through correspondence (pp. 7-10). Such research and networking activities have put him in a position to create a unique bibliography.

V. Cojocaru presents 5,057 titles dealing with the inscriptions and coins found on the northern shores of the Black Sea and treating persons or names attested in or for the area. The chronological limits are the archaic period at the one end and the dusk of the High Roman Empire at the other. The overall structure of the bibliography is mainly geographical, covering (often with some adjacent territories) Achilleos Nesos (I: pp. 63f.), Tyras and Nikonion (II: pp. 65ff.), Borysthenes and Olbia (III: pp. 87ff.), Karkinitis and Chersonesos Taurike (IV: pp. 158ff.), Neapolis Skythike (V: pp. 225ff.) and the Bosporan Kingdom (VI: pp. 228ff.). Several further works largely relating to the Epigraphy or Numismatics of the Black Sea area that remain without a narrow geographical circumscription follow (VII: pp. 389ff.). Next come studies that address documents in Iranian or including Iranian elements (pp. 477ff.), to which a very brief section on Cimmerian Onomastics (p. 491) is added. An appendix of mostly very recent titles (pp. 492-494) reveals that V. Cojocaru continued to collect and integrate titles until the very end of the editorial process of the book. Within these (geographical or ethno-linguistic) chapters, the methodolical subdivision is for the most part four-fold: A. Epigrapica; B. Numismatica; C. Pondera; D. Onomastica et prospographica. Under these categories, publications are listed in alphabetical order. The structure appears straight forward and has been set out lucidly in the introduction (pp. 12-14, cf. table of contents, pp. 5f.). Worth mentioning is also the list of abbreviations (pp. 16-61), in itself a useful instrument. A threepartite index accessible by epigraphic collections, authors and reviewers, as

\section{Altay Coşkun}

\section{University of Waterloo}

acoskun@uwaterloo.ca

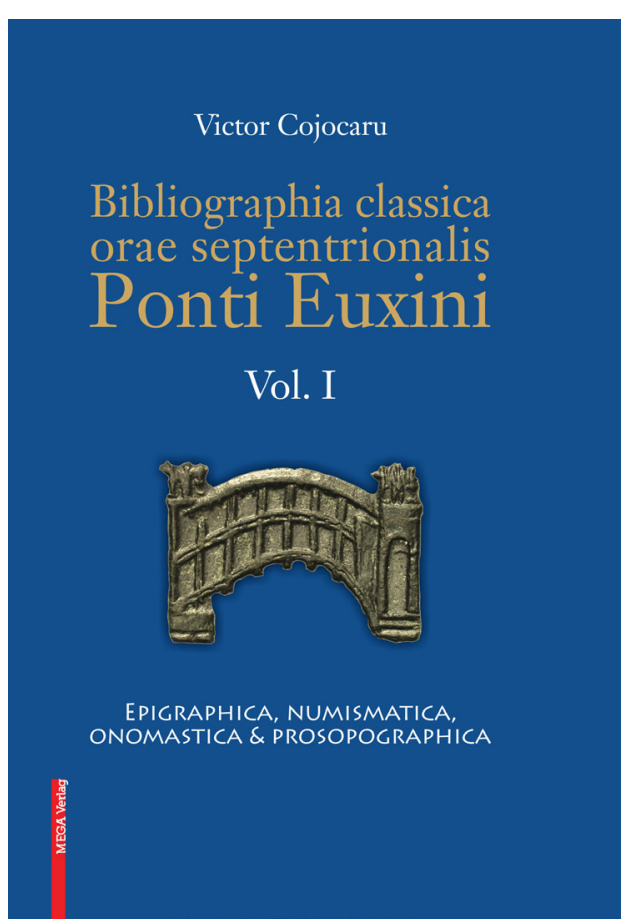

DOI: http://dx.doi.org/10.14795/j.v1i3.62

ISSN $2360-266 \mathrm{X}$

ISSN-L 2360 - 266X 
well as further names and objects complete the work (pp. 495-560).

The attempt of achieving completeness (from early modern times until 2013) is bold, but it appears to me that V. Cojocaru has come very close to this goal. Most of the very few titles that I found missing in a preliminary version of the book had been withheld deliberately, since they will fit better in one of the volumes that are still in preparation. It is stunning to understand that "Epigraphica, numismatica, onomastica \& prosopographica" is only the first of a planned series of five volumes, which the preface mentions in passing (p. 9): the current plan further comprises Archaeologica (II.), Ars, res sacrae et mythologica (III.), Historica et historiographica (IV) as well as Varia, addenda et corrigenda (V.). This work required a long and painstaking editorial process. It is clear that the whole undertaking depended on a lot of personal and institutional support, which V. Cojocaru generously and kindly acknowledges on pp. 16f. (also p. 9), most of all he expresses his gratitude to Joachim Hupe (Trier, Germany), himself an expert of the Black Sea, who is familiar with the many languages involved.

The amount of scholarship produced on the ancient Black Sea, as presented in this unique bibliography, clearly went beyond my expectation. The collection of this material appears to have been as much an Herculean task as its editing into a correct, consistent and accessible bibliography, with all titles of an Eastern European language first transcribed into the Latin alphabet and then translated into German. Of particular value are the references to book reviews or discussions in Bulletin Épigraphique, Année Épigraphique or Supplementum Epigraphicum Graecum after several of the entries. It is fortunate that not only the references included in the official title of books and articles, but also the ones thus annotated by V. Cojocaru, have found their way into the register, which have been crafted with an attempt at completeness, besides the utmost diligence that characterises the whole book.

For a number of reasons, it is worthwhile comparing BCOSPE with the $4^{\text {th }}$ edition of the Bibliography of Ancient Slavery, which compiled 10,415 titles until 2003 (Heinz Bellen \& Heinz Heinen, Bibliographie zur antiken Sklaverei. Forschungen zur antiken Sklaverei, Beiheft 4. Two vols. Stuttgart: Franz Steiner Verlag, 2003. Pp. xiv, viii, 805). The latter project had been started in the 1950s and was equipped with a lot more institutional resources at the Mainz Academy. This notwithstanding, BCOSPE will eventually surpass the size of the slavery bibliography, and certainly will have no less impact on scholarship. Stanford Professor and reviewer Walter Scheidel expresses his admiration for the accomplished task of the Mainz Academy, though not without asking for a CD ROM to facilitate the usability (Bryn Mawr Classical Review 2005.09.39). BCOSPE I comes with a CD ROM that includes a fully readable pdf file. Users can easily download the whole book onto their computers, there are no tedious restrictions implemented by the publisher (as is unfortunately so often the case). All kinds of word searches that Acrobate Reader supports can be pursued with the utmost ease. Book titles can simply be copy-pasted into word documents, without having to use any complicated or costly software.

In all fairness, the bibliography of the Mainz Academy is now even fully searchable on the project website. It would thus be a long-term goal that the Publisher MEGA of BCOSPE or the Romanian Academy one day provide a similar service on their websites. And if I may mention another desideratum: while browsing through the titles, I often wished to have access to at least a very brief abstract. I am well aware that it is practically impossible to add these to every work cited in volumes I-V. However, since clearly not every title is of equally lasting value on the one hand, but some 'pearls', especially among the older or more remote scholarship might get buried in the sheer amount of references, I wonder if $\mathrm{V}$. Cojocaru may one day put together a collaborative team with the intention of producing an enchiridion compiling - say, up to a thousand - abstracts of the most rewarding scholarly publications on the Northern Black Sea area in antiquity.

The importance of BCOSPE, its scope and the diligence of its implementation do not leave any room for doubt that this book will become a standard work for everyone working on the Ancient Black Sea Region. It is a powerful continuation of the recently established series Pontica et Mediterranea. The MEGA Publishing House can be grateful to have been offered this manuscript (and series), which would certainly have been welcomed also by major publishers in Western Europe. The author and the series editors, in turn, have to be grateful for the excellent production of this book with its aesthetic and efficient type setting as well as its attractive and solid cover. All of this recommends MEGA.

As an alumnus and former assistant of Prof. Heinen, I am aware that the latter supported V. Cojocaru's work for many years and would be as glad to see this first volume of the monumental bibliographical project accomplished as he would feel honoured to be its dedicatee. Certainly, the scholarly community will be indebted to V. Cojocaru, for the production of this rich and meticulous research tool. It is with impatience that the publication of the subsequent volumes of BCOSPE will be expected. 